\title{
MAKNA TINDAKAN-TINDAKAN DALAM MBOLO WEKI PROSESI PERNIKAHAN TRADISI MASYARAKAT BIMA.
}

\author{
M. Tahir \\ mtahirt14@gmail.com
}

\begin{abstract}
Abstrak. Masalah yang dibahas dalam penelitian ini adalah tindakan-tindakan yang terdapat dalam Mbolo Weki prosesi pernikahan tradisi masyarakat Bima menggunakan kajian semiotika Roland Barthes dan makna tindakan-tindakan dalam Mbolo Weki prosesi pernikahan tradisi masyarakat. Metode penelitian yaitu, metode dokumentasi dan wawancara. Dalam menganalisis data menggunakan pendekatan deskriptif perspektif Roland Barthes. Hasil penelitian ini berupa pendeskripsian data menunjukan 6 tindakan yang menggambarkan makna yaitu, doho ka mbolo, piti kumpula, kumpula uta, pembentukan panitia pernikahan dan kancihi ncao fiki ro kananu kasabua ade ro loko. Dari makna yang digambarkan bahwa acara Mbolo Weki prosesi pernikahan memiliki makna bahwa Mbolo Weki merupakan suatu acara yang dilakukan secara terhormat dalam tradisi prosesi pernikahan yang bertujuan untuk mempererat hubungan dalam kesatuan sosial masyarakat, seperti adanya bantuan dari kelompok orang, yang dimaksudkan dengan adanya pemberian sumbangan secara bergilir dengan tujuan salah satunya untuk meringankan beban biaya pernikahan keluarga yang berhajat, dan tradisi ini sangat bermanfaat untuk berbagai kalangan sosial dalam masyarakat suku Bima.
\end{abstract}

Kata Kunci: Mbolo Weki prosesi pernikahan,, tindakan. 


\section{PENDAHULUAN}

Daerah Nusantara ini kaya dengan berbagai macam seni dan budaya. Berbagai budaya masyarakat, tradisi, adat istiadat dan kebiasaan yang dilakukan secara turun temurun dari setiap nenek moyang yang berbeda-beda menghasilkan seni budaya yang berbeda-beda pula. Contohnya masyarakat Bima, yang merupakan suatu daerah yang kaya akan budaya, tradisi dan adat istiadat, yang merupakan ciri khas masyarakat itu. Salah satu tradisinya adalah acara Mbolo Weki untuk mempersiapkan prosesi pernikahan, yaitu acara musyawarah mufakat yang membahas terkait dengan pemberian sumbangan, pelaksanaan acara, panitia pelaksana dan lain-lain.

Hal-hal yang dimusyawarahkan dalam Mbolo Weki untuk mempersiapkan prosesi pernikahan biasanya seperti pengumpulan uang, beras, hewan ternak, dari keluarga terdekat. Dalam kegiatan tersebut dimusyawarahkan juga tentang penentuan hari baik, pembagian tugas (kepanitiaan acara, mendata segala kebutuhan dan keperluan acara, menyepakati apa-apa yang akan dilaksanakan selama berlangsungnya acara tersebut. Sedangkan kaum perempuan/ibu- ibu biasanya akan bermusyawarah atau dipercaya untuk menentukan hal-hal yang berbeda dengan kaum laki-laki. Masalah yang dibahas cenderung kepada apa-apa yang membutuhkan ketelitian lebih yang dikuasai oleh kaum perempuan/ibu-ibu, seperti perbendaharaan anggaran, konsumsi, peralatan masak, tata rias, juga terkait apa-apa yang harus dibelanjakan.

Bagi masyarakat Bima, acara Mbolo Weki untuk mempersiapkan prosesi pernikahan merupakan tradisi yang sudahlama dilakukan dan harus dipertahankan, karena Mbolo Weki prosesi pernikahan adalah warisan para nenek moyang sejak zaman dahulu yang dilakukan secara turun temurun yang melibatkan bapak-bapak, ibu-ibu, dan tetua-tetua dari keluarga terdekat. Dalam tradisi ini, ada beberapa hal unik yang menarik untuk diteliti yaitu yang pertama tradisi ini sudah ada sejak zaman dahulu, pada saat itu pelaksanaan
Mbolo Weki prosesi pernikahan masih sangat kental sedangkan pada zaman sekarang justru sebagian orang hanya mengetahui yang dinamakan dengan istilah "Musyawarah Mufakat". Kegiatan ini sebenarnya tidak jauh berbeda dengan "Mbolo Weki", karena kegiatan musyawarah mufakat yang biasanya dilaksanakan di setiap kantor atau lembaga lainnya mereka hanya membahas terkait dengan pelaksanaan acara yang ingin dilaksanakan saja.

Sejak zaman dulu orang-orang yang datang (weki) khususnya ibu-ibu tidak hanya datang dengan tangan kosong, melainkan mereka membawa beras dengan menggunakan Boko. Boko ini berbentuk seperti gelas yang memiliki kaki yang terbuat dari tembaga berwarna keemasan dan juga mengandung unsur emas. Pada saat itu, alat ini sering digunakan ketika ada acara hajatan keluarga dan pemberian zakat fitrah, karena Boko ini berukuran sama dengan 1 gantang (4 liter). Pada masa sekarang keberadaan Boko ini sudah tidak ada/sulit untuk didapat dan ditemukan sehingga orang-orang yang datang dalam acara Mbolo Weki tidak ada yang membawa beras dengan menggunakan Boko, bukan karena tidak adanya alat tersebut, tetapi karena zaman sekarang mereka langsung menyumbang dengan uang. Jadi, keluarga yangmenyelenggarakan acara tidak akan menanggung sendiri beban materil dalam menyelenggarakan acara tersebut. Hal tersebut yang membuat peneliti tertarik ingin mengkaji makna tindakan-tindakan yang terdapat pada tradisi Mbolo Weki prosesi pernikahan dengan menggunakan kajian Roland Barthes, yang mencakup 2 tingkatan penandaan, yaitu tingkat denotasi (makna sebenarnya sesuai kamus) dan konotasi (makna ganda yang lahir dari pengalaman kultural dan personal).

\section{METODE PENELITIAN}

Penelitian ini merupakan jenis penelitian deskripsi kualitatif, yaitu penelitian yang memanfaatkan wawancara terbuka untuk menelaah dan memahami sikap, pandangan, perasaan, dan perilaku individu atau sekelompok orang. Penelitian kualitatif menurut Denzin dan Lincoln (1987) (dalam 
Moleong, 2016:5) menyatakan bahwa penelitian kualitatif adalah penelitian yang menggunakan latar alamiah, dengan maksud menafsirkan fenomena yang terjadi dan dilakukan dengan jalan melibatkan berbagai metode yang ada. Oleh karena itu, penelitian kualitatif adalah penelitian yang bermaksud untuk memahami fenomena tentang apa yang dialami oleh subjek penelitian misalnya perilaku, persepsi, motivasi, tindakan, dll., secara holistik, dan dengan cara deskripsi dalam bentuk kata-kata dan bahasa, pada suatu konteks khusus yang alamiah dengan memanfaatkan berbagai metode ilmiah.

Menurut teori penelitian kualitatif, agar penelitiannya dapat betul-betul berkualitas data yang dikumpulkan harus lengkap, seperti data dalam bentuk verbal atau kata-kata yang diucapkan secara lisan oleh informan mengenai tata carapelaksanaan Mbolo Weki untuk mempersiapkan prosesi pernikahan. Selain itu, ada juga data yang diperoleh dari dokumen-dokumen, foto-foto, film, rekaman video, benda-benda, dan lainlain, seperti dalam acara Mbolo Weki prosesi pernikahan tradisi masyarakat Bima yaitu berupa foto-foto dan rekaman video proses acara Mbolo Weki yang dilaksanakan dari awal sampai berakhirnya pengumpulan data.

Sumber data yang dimaksud oleh Arikunto (2013:172) dalam suatu penelitian adalah dari mana subjek data dapat diperoleh. Sumber data pada penelitian kualitatif ini adalah tampilan yang berupa kata-kata lisan atau tertulis yang berupa penjelasan terkait dengan pelaksanaan acara Mbolo Weki prosesi pernikahan yang dicermati oleh peneliti, dan tata cara yang diamati secara detail agar dapat ditangkap makna yang tersirat.

Berdasarkan uraian di atas, yang menjadi sumber data dalam penelitian ini adalah acara Mbolo Weki yang di dalamnya berupa tata cara atau sesuatu yang dijadikan sebagai tindakan dalam proses acara tersebut yang memiliki makna khusus, yang terdapat pada masyarakat Bima.

Metode pengumpulan data dalam penelitian ini antara lain:

1. Metode Dokumentasi
Metode dokumentasi adalah sebagai suatu cara pengumpulan data kualitatif dengan melihat atau menganalisis dokumendokumen. Dengan metode ini, peneliti mengumpulkan data yang diperoleh dari catatan-catatan, foto-foto dan sebagainya.

2. Metode Wawancara

Metode wawancara adalah percakapan dengan maksud tertentu. Percakapan itu dilakukan oleh dua pihak, yaitu pewawancara (interviewer) yang mengajukan pertanyaan dan terwawancara (interviewer) yang memberikan jawaban atas pertanyaan itu (Moleong, 2016:186)

Analisis data dalam penelitian ini adalah menggunakan metode deskriptif kualitatif Data yang dikumpulkan dalam bentuk tindakan-tindakan yang memiliki makna khusus dalam acara Mbolo Weki prosesi pernikahan tradisi masyarakat Bima.

Dalam penelitian ini, pada penyajian hasil peneliti menggunakan metode deskriptif analisis atau analisis deskripsi. Metode deskriptif analitik ini dilakukan dengan cara mendeskripsikan fakta-fakta yaang kemudian disusul dengan analisis (Ratna, 2012:53).

Peneliti menggunakan metode deskriptif analitik ini untuk mendeskripsikan fakta-fakta (dalam bentuk tindakantindakan) yang terdapat pada acara Mbolo Weki prosesi pernikahan tradisi masyarakat Bima, yang kemudian dianalisis menggunakan teori semiologi Roland Barthes. Tindakan-tindakan tersebut terdapat pada proses acara Mbolo Weki prosesi pernikahan dari awal sampai selesai. Adapun tindakan-tindakan yang dimaksud dalam acara Mbolo Weki tersebut yaitu, tata cara pelaksanaannya, dan tekar ne'e (pemberian sumbangan).

\section{PEMBAHASAN}

Pelaksanaan acara Mbolo Weki prosesi pernikahan ini, pada umumnya dilaksanakan setelah ba'da sholat Isya, yang bertempat di rumah keluarga yang akan melaksanakan sebuah hajatan. Ketika pelaksanaan Mbolo Weki prosesi pernikahan dimulai, keluarga yang berhajat biasanya langsung menyediakan berbagai kebutuhan guna melancarkan dan 
memeriahkan jalannya acara seperti konsumsi, yang dimaksud konsumsi ini ialah jajanan yang meliputi makanan tradisional dengan menggunakan sebuah alat seperti tare (talam) dan minuman yang terdiri dari teh dan kopi, yang akan disuguhi kepada para tamu undangan yang menghadiri acara Mbolo Weki prosesi pernikahan. Proses selanjutnya yang dibahas adalah, piti kumpula yang berarti kumpulan uang dari organisasi persatuan kekeluargaan lingkungan, yang telah disepakati oleh masyarakat. Sumbangan dana setiap individu yang diundang tersebut bersifat arisan atau bergilir, yang dimaksud ialah bahwa setiap individu yang hidup dalam kelompok masyarakat suku Bima maka akan diberlakukan pula sumbangan bergilir tersebut. Sumbangan dana tersebut, akan dikumpulkan melalui bendahara I yang sudah ditunjuk untuk menerima dana setiap ada acara hajatan, pengumpulan uang tersebut bisa dikumpulkan ketika acara Mbolo Weki berlangsung jika ada yang membawa uang kumpulan, dan bagi yang belum membawa uang bisa langsung menyerahkan kepada bendahara kapan saja, tetapi sebelum acara prosesi pernikahan dilangsungkan. Karena piti kumpula itu nantinya akan diserahkan oleh bendahara kepada keluarga yang berhajat untuk digunakan terkait dengan acara prosesi pernikahan. Sedangkan, ibu- ibu juga memiliki sumbangan tersendiri yaitu kumpula uta (persatuan ibu-ibu yang memberikan sumbangan $1 \mathrm{~kg}$ daging/orang). Sumbangan berupa $1 \mathrm{~kg}$ daging ini, sama dengan piti kumpula tadi setiap individu yang diundang tersebut bersifat arisan atau bergilir, yang dimaksud ialah bahwa setiap individu yang hidup dalam kelompok masyarakat suku Bima maka akan diberlakukan pula sumbangan bergilir tersebut. Sumbangan $1 \mathrm{~kg}$ daging tersebut, akan dikumpulkan berupa uang Rp. 100.000/ individu melalui bendahara II yang sudah ditunjuk untuk menerima dana setiap ada acara hajatan, pengumpulan uang tersebut bisa dikumpulkan ketika acara Mbolo Weki berlangsung jika ada yang membawa uang kumpulan, dan bagi yang belum membawa uang tidak bisa langsung menyerahkan kepada bendahara kapan saja, tetapi sebelum acara prosesi pernikahan dilangsungkan. Karena kumpula uta itu nantinya akan diserahkan oleh bendahara kepada keluarga yang berhajat yang digunakan untuk tambahan membeli daging.

Kemudian dilanjutkan dengan proses pembentukan panitia pernikahan. Dalam pembentukan panitia, terdapat bagianbagiannya tersendiri antara lain: penasehat, ketua, sekretaris, dan seksi- seksi, di dalam seksi-seksi dibagi lagi menjadi 5 yaitu, ada yang namanya parenta (orang-orang yang mengetahui semuanya tentang masalah apa saja yang kurang), seksi penerima tamu, seksi perlengkapan/sound sistem, seksi dapur/konsumsi dan seksi acara. Orangorang yang menjadi panitia pernikahan ini biasanya adalah warga kampung itu sendiri, dan ada juga dari keluarga besar yang berhajat, tetapi sebagian besar yang menjadi panitia adalah warga kampung, sehingga setiap ada acara pernikahan di kampung tersebut yang menjadi panitianya adalah warga kampung juga, kegiatan ini bersifat bergilir.

\begin{tabular}{llr}
\multicolumn{2}{c}{ Pelaksanaan acara Mbolo } & Weki \\
prosesi pernikahan dimulai & dari \\
pemberitahuan dalam & kampung & dan
\end{tabular}
pemberitahuan luar kampung. Pemberitahuan dalam kampung, dalam tahap ini pihak keluarga yang berhajat menyampaikan informasi secara langsung serta bertatap muka dengan mendatangi rumah keluarga dan masyarakat. Sedangkan pemberitahuan luar kampung yaitu melalui media, yang dimaksud ialah proses pemberitahuan atau pembagian undangan kepada masyarakat yang berada di luar kampung. Selanjutnya pemberitahuan luar kampung, dalam tahap yang kedua ini keluarga yang berhajat akan melakukan pembagian undangan kepada masyarakat yang berada di luar kampung atau luar jangkauan dari masyarakat yang melaksanakan acara Mbolo Weki prosesi pernikahan terkait dengan tanggal dan waktu pelaksanaan acara Mbolo Weki, agar ada persiapan dari kerabat atau keluarga dekat. 
Hal selanjutnya yang akan dibahas dalam berlangsungnya acara Mbolo Weki ialah membicarakan terkait dengan dalam bentuk apa warga masyarakat akan mbei sumbangan (pemberian sumbangan) untuk keluarga yang berhajat. Pemberiannya bisa bermacam-macam, bisa berupa uang tunai, hewan ternak, padi/beras, hasil kebun, dan lain sebagainya sesuai kapasitas dan kemampuan masing-masing orang. Dalam konteks acara pernikahan, Mbolo Weki terkesan filosofis sekali. Tetua-tetua keluarga dari anak yang akan menikah beserta kerabat yang menghadiri Mbolo Weki akan memberikan bantuan yang bukan hanya untuk terselenggaranya acara, melainkan sebagai bekal bagi anak yang menikah itu. Bekal-bekal tersebut seperti peralatan ibadah, pakaian dan sarung adat. Tak terlewatkan juga, bekal seperti beras dalam jumlah yang cukup banyak, hewan ternak, sebidang tanah dan semacamnya. Hal ini melambangkan betapa orang tua beserta keluarga besar ingin melepas anaknya menuju kehidupan dan tanggung jawab baru, dengan modal yang cukup secara materil dan juga moril. Tetapi pada zaman sekarang, kebanyakan orang-orang akan memberikan sumbangsih berupa piti kumpula (uang kumpulan) yang biasa dilakukan oleh setiap keluarga ketika ada acara hajatan yang akan dilaksanakan yang telah disepakati bersama. Sumbangan dana setiap keluarga yang diundang tersebut bersifat arisan atau bergilir, yang dimaksud ialah bahwa setiap individu yang hidup dalam kelompok masyarakat suku Bima maka akan diberlakukan pula sumbangan bergilir tersebut. Piti kumpula mempunyai makna bahwa warga masyarakat melakukan pengumpulan uang dan keluarga yang berhajat akan menerima sumbangan tersebut. Sumbangan dana tersebut, akan dikumpulkan melalui bendahara I yang sudah ditunjuk untuk menerima dana setiap ada acara hajatan. Piti kumpula itu nantinya akan diserahkan oleh bendahara kepada keluarga yang berhajat untuk digunakan terkait dengan acara prosesi pernikahan. Sedangkan ibu- ibu juga memiliki kumpulan tersendiri yaitu kumpula uta (kumpulan uang ibu-ibu yang memberikan sumbangan $1 \mathrm{~kg}$ daging). Sumbangan berupa $1 \mathrm{~kg}$ daging ini, sama dengan piti kumpula tadi setiap individu yang diundang tersebut bersifat arisan atau bergilir, yang dimaksud ialah bahwa setiap individu yang hidup dalam kelompok masyarakat suku Bima maka akan diberlakukan pula sumbangan bergilir tersebut. Sumbangan 1 $\mathrm{kg}$ daging tersebut, akan dikumpulkan berupa uang $\mathrm{Rp}$.

100.000/ individu melalui bendahara II yang sudah ditunjuk untuk menerima dana setiap ada acara hajatan, pengumpulan uang tersebut bisa dikumpulkan ketika acara Mbolo Weki berlangsung jika ada yang membawa uang kumpulan, dan bagi yang belum membawa uang bisa langsung menyerahkan kepada bendahara kapan saja, tetapi sebelum acara prosesi pernikahan dilangsungkan. Karena kumpula uta itu nantinya akan diserahkan oleh bendahara kepada keluarga yang berhajat yang digunakan untuk tambahan membeli daging.

Proses dilakukan setelah membahas terkait dengan pemberian sumbangsih atau bantuan dari warga masyarakat yaitu semua kepala keluarga yang hadir akan melakukan pembentukan panitia pernikahan yaitu kegiatan yang dilakukan untuk membantu proses pelaksanaan prosesi pernikahan yang di dalamnya terdapat bagian-bagiannya tersendiri antara lain: penasehat, ketua, sekretaris, dan seksi-seksi, di dalam seksiseksi dibagi lagi menjadi 5 yaitu, ada yang namanya parenta (orang-orang yang mengetahui semuanya tentang masalah apa saja yang kurang), seksi penerima tamu, seksi perlengkapan/sound sistem, seksi dapur/konsumsi dan seksi acara. Orangorang yang menjadi panitia pernikahan ini biasanya adalah warga kampung itu sendiri, dan ada juga dari keluarga besar yang berhajat, tetapi sebagian besar yang menjadi panitia adalah warga kampung, sehingga setiap ada acara pernikahan di kampung tersebut yang menjadi panitianya adalah warga kampung juga, kegiatan ini bersifat bergilir. 
Setelah selesai membahas terkait dengan pembentukan panitia pernikahan, semua warga yang hadir harus sama-sama kancihi ncao fiki ro kananu kasabua ade ro loko (menyelaraskan pikiran dan renungan, menyatukan hati dan rasa) agar segala hal yang telah dibahas dalam acara Mbolo Weki tersebut bisa disepakati bersama tanpa adanya perbedaan pendapat antara satu sama lain, sehingga akan terciptanya sebuah kesepakatan untuk pelaksanaan acara prosesi pernikahan nanntinya. Kancihi ncao fiki ro kananu kasabua ade ro loko akan menciptakan kedamaian dan kebersamaan masyarakat dalam merancang segala hal terkait dengan pelaksanaan acara tersebut.

Berdasarkan pemaparan di atas, mengenai tahapan-tahapan yang dilakukan dalam Mbolo Weki prosesi pernikahan tradisi masyarakat Bima ditemukan sebanyak 5 tindakan dalam tradisi ini yaitu, doho $\mathrm{ka}$ mbolo, piti kumpula, kumpula uta, pembentukan panitia pernikahan, dan yang berwujud pesan nonverbal adalah kancihi ncao fiki ro kananu kasabua ade ro loko. Kemudian dari lima tindakan yang telah ditemukan tersebut peneliti memilih tanda untuk mengetahui makna yang terdapat pada acara Mbolo Weki prosesi pernikahan tradisi masyarakat Bima yaitu:

1. Doho ka mbolo (duduk melingkar)

2. Piti kumpula (kumpulan uang dari organisasi persatuan kekeluargaan lingkungan)

3. Kumpula uta (persatuan ibu-ibu yang memberikan sumbangan $1 \mathrm{~kg}$ daging)

4. Pembentukan panitia pernikahan

5. Kancihi ncao fiki ro kananu kasabua ade ro loko (menyelaraskan pikiran dan renungan, menyatukan hatiintuisi dan rasa)

Hal tersebut akan dijabarkan sebagai berikut:

\begin{tabular}{|c|c|c|}
\hline 1. Signifier & 2. Signified & 3. Sign \\
\hline \multicolumn{2}{|c|}{ I SIGNIFIER } & II SIGNIFIED \\
\hline \multicolumn{3}{|c|}{ III SIGN } \\
\hline
\end{tabular}

Keterangan :
1. Signifier/penanda (1) penanda dalam ranah denotasi

2. Signified/petanda (2) petanda dalam ranah denotasi

3. Sign/tanda (3) tanda dalam ranah denotasi, tanda (3) ini sekaligus merupakan petanda baru/petanda (I) pada ranah konotasi yang terdapat pada signifikasi kedua

4. Signifier/penanda (I) penanda dalam ranah konotasi

5. Signified/petanda (II) petanda dalam ranah konotasi

6. Sign/tanda (III) tanda dalam ranah kontasi

Keterangan angka (1,2, dan 3) termasuk ranah denotasi, dan angka romawi (I,II, dan III) termasuk ranah kontasi.

\section{ANALISIS DATA}

Analisis data pada penelitian ini menjelaskan proses pembentukan makna menggunakan lima tanda.

\section{Doho ka mbolo}

\begin{tabular}{|c|c|c|}
\hline $\begin{array}{l}\text { 1. Doho ka } \\
\text { mbolo } \\
\text { (duduk } \\
\text { melingkar) }\end{array}$ & $\begin{array}{ll}\text { 2. } & \text { Akan } \\
\text { diadakan } \\
\text { kegiatan } \\
\text { musyawar } \\
\text { ah } \\
\text { mufakat }\end{array}$ & \\
\hline \multicolumn{2}{|c|}{$\begin{array}{l}\text { 3./I. Adanya sebuah acara } \\
\text { yang } \\
\text { diselenggarakan }\end{array}$} & $\begin{array}{l}\text { II.Untuk } \\
\text { menyat } \\
\text { ukan } \\
\text { pendap } \\
\text { at }\end{array}$ \\
\hline $\begin{array}{l}\text { III. Akan te } \\
\text { bersama }\end{array}$ & ipta sebuah & \\
\hline
\end{tabular}

\section{Keterangan}

Penanda (1 signifier) "doho $k a$ mbolo" tanda ini menempati petanda (1) pada ranah denotatif. Penanda tersebut menjelaskan bahwa tahapan pertama yang dilakukan dalam acara Mbolo Weki prosesi pernikahan adalah dengan cara duduk berkumpul secara melingkar yang dilakukan oleh orang-orang yang datang 
(weki). Penanda (1) ini membuahkan petanda (2) pada ranah denotatif. Petanda (2 signified) ini adalah "akan diadakan kegiatan musyawarah mufakat". Petanda (2) ini menjelaskan bahwa ketika semua kepala keluarga telah duduk membentuk lingkaran berarti akan ada kegiatan musyawarah mufakat untuk membahas terkait dengan acara yang akan diselenggarakan. Hal ini dilakukan oleh orang-orang yang akan melaksanakan kegiatan Mbolo Weki.

Tanda (3 tanda denotatif) pada ranah denotatif ini sekaligus menjadi penanda (I) pada ranah konotatif. Tanda (3/I penanda konotatif) yang dimaksud adalah "adanya sebuah acara yang akan diselenggarakan”. Tanda ini menjelaskan bahwa dilaksanakannya acara Mbolo Weki ini karena akan ada sebuah hajatan yang akan diselenggarakan yaitu prosesi pernikahan. Pada tahap pertama "doho ka mbolo" (duduk melingkar), memberikan penjelasan bahwa sebelum memulai acara Mbolo Weki prosesi pernikahan terlebih dahulu warga harus duduk berkumpul secara melingkar agar bisa menyatukan pendapat antara satu sama lain. Tanda ini terbentuk karena adanya penanda dan petanda para ranah denotatif yang tidak bisa terpisahkan, yang saling melengkapi, sehingga menghasilkan tanda pada ranah denotatif yang sekaligus menjadi penanda pada ranah konotatif. Tanda (3/I) memunculkan penanda (II) pada ranah konotatif yaitu "untuk menyatukan pendapat". Jadi, tujuan dari duduk berbentuk lingkaran tersebut yaitu untuk menyatukan pendapat antara satu sama lain untuk mencapai suatu kesepakatan. Kemudian dari penanda (II petanda konotatif) pada ranah konotatif ini melahirkan tanda (III) pada ranah konotatif yaitu "akan tercipta sebuah kesepakatan bersama”.

Tanda (III tanda konotatif) ini merupakan kesimpulan dari pertemuan antara penanda (I) dan petanda (II) pada ranah konotatif yang mengahasilkan sebuah makna. Maknanya adalah ketika acara Mbolo Weki prosesi pernikahan akan dilaksanakan maka semua kepala keluarga yang hadir terlebih dahulu akan duduk secara melingkar dengan tujuan agar bisa menyatukan dan mempersatuan pendapat sehingga akan ada sebuah kesepakatan bersama antara semua warga yang hadir.

\section{Piti kumpula}

\begin{tabular}{|l|l|l|}
\hline $\begin{array}{c}\text { 1. Putiti } \\
\text { (uang } \\
\text { kumpulan) }\end{array}$ & $\begin{array}{l}\text { 2. Akan ada } \\
\text { acara } \\
\text { hajatan }\end{array}$ & \\
\hline $\begin{array}{l}\text { 3./I. Adanya } \\
\text { pernikahan }\end{array}$ & prosesi & $\begin{array}{l}\text { II. Dua } \\
\text { orang } \\
\text { yang } \\
\text { akan } \\
\text { menikah }\end{array}$ \\
\hline $\begin{array}{l}\text { III. Telah disetujui oleh dua pihak } \\
\text { keluarga }\end{array}$ & \\
\hline
\end{tabular}

\section{Keterangan}

Penanda (1 signifier) "piti kumpula" tanda ini menempati petanda (1) pada ranah denotatif. Penanda tersebut menjelaskan bahwa tahapan kedua yang dilakukan dalam acara Mbolo Weki prosesi pernikahan adalah melakukan pengumpulan "piti kumpula" yang dilakukan oleh seluruh warga yang hadir dalam acara Mbolo Weki tersebut untuk membantu keluarga yang berhajat dan dikumpulkan melalui bendahara I. Penanda (1) ini membuahkan petanda (2) pada ranah denotatif. Petanda (2 signified) ini adalah “akan ada acara hajatan" Petanda (2) ini menjelaskan bahwa dalam kehidupan bermasyarakat, harus saling membantu memberikan sumbangan ketika ada warga yang akan melaksanakan sebuah acara hajatan karena kegiatan ini juga dilakukan secara bergilir. Hal ini dilakukan warga masyarakat agar tali persaudaraan tetap solid dalam menjalin hubungan kekeluargaan.

$$
\text { Tanda (3 tanda denotatif) pada }
$$

ranah denotatif ini sekaligus menjadi penanda (I) pada ranah konotatif. Tanda (3/I penanda konotatif) yang dimaksud adalah "adanya prosesi pernikahan". Tanda ini menjelaskan bahwa terdapat sumbangan dana dari warga masyarakat yang mengikuti acara Mbolo Weki tersebut karena 
akan diadakan prosesi pernikahan yang diselenggarakan oleh keluarga yang melaksanakan acara hajatan. Pada tahap ketiga "piti kumpula" (kumpulan uang persatuan kekeluargaan lingkungan), memberikan penjelasan bahwa ketika melaksanakan tradisi Mbolo Weki prosesi pernikahan pastinya ada yang dinamakan mengumpulkan sumbangan berupa uang dari masing-masing keluarga, yang bertujuan untuk membantu meringankan beban materil keluarga yang berhajat dalam melaksanakan acaranya dan kegiatan ini dilakukan secara bergilir ketika ada acara hajatan warga masyarakat lainnya juga. Tanda ini terbentuk karena adanya penanda dan petanda para ranah denotatif yang tidak bisa terpisahkan, yang saling melengkapi, sehingga menghasilkan tanda pada ranah denotatif yang sekaligus menjadi penanda pada ranah konotatif. Tanda (3/I) memunculkan penanda (II) pada ranah konotatif yaitu "dua orang yang akan menikah". Jadi, adanya kegiatan mengumpulkan sumbangan berupa uang karena adanya sepasang kekasih yang akan menikah karena telah disetujui oleh orangtua mereka untuk melanjutkan ke jenjang pernikahan. Kemudian dari penanda (II petanda konotatif) pada ranah konotatif ini melahirkan tanda (III) pada ranah konotatif yaitu "telah disetujui oleh dua pihak keluarga". Tanda (III tanda konotatif) ini merupakan kesimpulan dari pertemuan antara penanda (I) dan petanda (II) pada ranah konotatif yang mengahasilkan sebuah makna. Maknanya adalah ketika diadakannya acara Mbolo Weki prosesi 3./I. Adanya ibu-ibu yang memberikan sumbangan $1 \mathrm{~kg}$ daging

II. Sebagai wujud kebersa maan pernikahan maka dilakukanlah pengumpulan sumbangan yang berupa uang dari warga masyarakat yang mengikuti acara tersebut untuk membantu keluarga yang melaksanakan sebuah hajatan yaitu prosesi pernikahan anaknya yang telah disetujui oleh dua pihak keluarga.

$$
\text { Penjelasan di atas dapat }
$$

disimpulkan bahwa piti kumpula merupakan kumpulan uang sumbangan dari persatuan kekeluargaaan lingkungan untuk disumbangkan kepada keluarga yang melaksanakan sebuah hajatan dan kegiatan ini dilakukan secara bergilir ketika ada acara hajatan warga masyarakat lainnya juga sehingga tali persaudaraan antara warga masyarakat tetap solid. Piti kumpula yang telah dikumpulkan kepada bendahara I nantinya akan diserahkan langsung pada keluarga yang berhajat setelah semua sudah terkumpul sehingga sumbangan tersebut bisa langsung digunakan.

\section{Kumpula uta}

III. Kerukunan warga antara satu sama lain

\section{Keterangan}

Penanda (1 signifier) "kumpula uta" tanda ini menempati petanda (1) pada ranah denotatif. Penanda tersebut menjelaskan bahwa tahapan ketiga yang dilakukan dalam acara Mbolo Weki prosesi pernikahan adalah ibu-ibu melakukan pengumpulan "kumpula uta" yang dilakukan oleh semua ibu-ibu yang hadir dalam acara Mbolo Weki tersebut untuk membantu keluarga yang berhajat dalam hal konsumsi dan kumpula uta tersebut akan dikumpulkan melalui bendara II. Penanda (1) ini membuahkan petanda (2) pada ranah denotatif. Petanda (2 signified) ini adalah “akan ada prosesi pernikahan" Petanda (2) ini menjelaskan bahwa tujuan dari ibu-ibu memberikan kumpula uta dikarenakan akan ada prosesi pernikahan yang akan diselenggarakan oleh keluarga yang melaksanakan acara hajatan. Hal ini dilakukan oleh ibu-ibu warga masyarakat yang ada, agar tetap saling membantu antara satu sama lain ketika akan 1. Kumpulauta (kumpulan uang ibu- ibu yang memberikan sumbangan $1 \mathrm{~kg}$ daging)

2. Akan ada acara prosesi pernik ahan melaksanaka sebuah hajatan keluarga. Tanda (3 tanda denotatif) pada ranah denotatif ini sekaligus menjadi penanda (I) pada ranah konotatif. Tanda (3/I penanda konotatif) yang dimaksud adalah "adanya ibu-ibu yang memberikan sumbangan $1 \mathrm{~kg}$ daging". Tanda ini menjelaskan bahwa setiap ada acara prosesi pernikahan, ibuibu akan melakukan kumpula uta atau memberikan sumbangan uang untuk $1 \mathrm{~kg}$ 
daging agar beban keluarga yang berhajat bisa sedikit ringan dalam hal konsumsi. Pada tahap ketiga "kumpula uta" (kumpulan uang ibu-ibu yang memberikan sumbangan 1 $\mathrm{kg}$ daging), memberikan penjelasan bahwa ketika melaksanakan tradisi Mbolo Weki prosesi pernikahan pastinya kaum wanita atau ibu-ibu akan mengumpulkan sumbangan berupa uang untuk $1 \mathrm{~kg}$ daging, yang bertujuan untuk membantu meringankan beban materil keluarga yang berhajat dalam melaksanakan acaranya dan kegiatan ini dilakukan secara bergilir ketika ada acara hajatan warga masyarakat lainnya juga. Tanda ini terbentuk karena adanya penanda dan petanda para ranah denotatif yang tidak bisa terpisahkan, yang saling melengkapi, sehingga menghasilkan tanda pada ranah denotatif yang sekaligus menjadi penanda pada ranah konotatif. Tanda memunculkan penanda (II) pada ranah konotatif yaitu "sebagai wujud kebersamaan". Jadi, setiap ada acara prosesi pernikahan ibu-ibu akan melakukan kumpula uta tersebut sebagai wujud kebersamaan mereka sehingga tali persaudaraan mereka tetap solid dan harmonis. Kemudian dari penanda (II petanda konotatif) pada ranah konotatif ini melahirkan tanda (III) pada ranah konotatif yaitu "kerukunan warga antara satu sama lain”. wujud kerukunan mereka antara satu sama lain.

Penjelasan di atas dapat disimpulkan bahwa kumpula uta merupakan kumpulan uang ibuibu yang memberikan sumbangan $1 \mathrm{~kg}$ daging untuk disumbangkan kepada keluarga yang melaksanakan sebuah hajatan dan kegiatan ini dilakukan secara bergilir ketika ada acara hajatan warga masyarakat lainnya juga sehingga tali persaudaraan antara warga masyarakat tetap solid. Kumpula uta yang telah dikumpulkan kepada bendahara II nantinya akan diserahkan langsung pada keluarga yang berhajat setelah semua sudah terkumpul sehingga sumbangan tersebut bisa langsung digunakan

\section{Pembentukan panitia pernikahan}

Tanda (III tanda konotatif) ini merupakan kesimpulan dari pertemuan antara penanda (I) dan petanda (II) pada ranah konotatif yang mengahasilkan sebuah makna. Maknanya adalah ketika tradisi Mbolo Weki prosesi pernikahan sedang dilaksanakan maka dilakukanlah pengumpulan sumbangan yang berupa uang untuk $1 \mathrm{~kg}$ daging dari ibu-ibu warga masyarakat yang mengikuti acara tersebut untuk keluarga yang berhajat sebagai

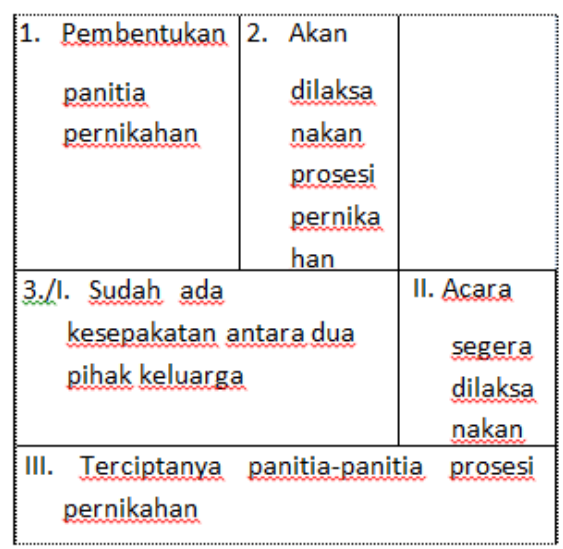

\section{Keterangan}

Penanda (1 signifier) "pembentukan panitia pernikahan" tanda ini menempati petanda (1) pada ranah denotatif. Penanda tersebut menjelaskan bahwa tahapan keempat yang dilakukan dalam acara Mbolo Weki prosesi pernikahan adalah melakukan "pembentukan panitia pernikahan" yang dilakukan oleh beberapa warga masyarakat yang sudah terbiasa dalam hal itu agar prosesi pernikahan nantinya bisa berjalan dengan lancar. Penanda (1) ini membuahkan petanda (2) pada ranah denotatif. Petanda (2 signified) ini adalah "akan dilaksanakan prosesi pernikahan" Petanda (2) ini menjelaskan bahwa dilakukannya pembentukan panitia pernikahan tersebut karena akan ada pelaksanaan prosesi pernikahan yang akan dilaksanakan oleh keluarga yang berhajat. Hal ini dilakukan oleh beberapa warga masyarakat yang sudah terbiasa dalam hal pembentukan panitia pernikahan sehingga acaranya bisa berjalan dengan lancar nantinya.

Tanda (3 tanda denotatif) pada ranah denotatif ini sekaligus menjadi penanda (I) pada ranah konotatif. Tanda (3/I penanda konotatif) yang dimaksud adalah "sudah ada kesepakatan antara dua pihak 
keluarga". Tanda ini menjelaskan bahwa sebelum prosesi pernikahan akan diselenggarakan, terlebih dahulu harus sudah ada kesepakatan antara kedua pihak keluarga, baru prosesi pernikahan bisa dilaksanakan karena jika belum ada kesepakatan antara kedua keluarga, prosesi pernikahan tidak akan bisa dilaksanakan. Pada tahap keempat "pembentukan panitia pernikahan", memberikan penjelasan bahwa sebelum melaksanakan prosesi pernikahan, terlebih dahulu membahas terkait dengan pembentukan panitia pelaksana agar acaranya bisa berjalan lancar dengan adanya panitia yang membantu. Tanda ini terbentuk karena adanya penanda dan petanda para ranah denotatif yang tidak bisa terpisahkan, yang saling melengkapi, sehingga menghasilkan tanda pada ranah denotatif yang sekaligus menjadi penanda pada ranah konotatif. Tanda (3/I) memunculkan penanda (II) pada ranah konotatif yaitu "acara segera dilaksanakan". Jadi, setelah pembentukan panitia telah dibentuk maka acara akan segera dilaksanakan. Kemudian dari penanda (II petanda konotatif) pada ranah konotatif ini melahirkan tanda (III) pada ranah konotatif yaitu "terciptanya panitia- panitia prosesi pernikahan".

Tanda (III tanda konotatif) ini merupakan kesimpulan dari pertemuan antara penanda (I) dan petanda (II) pada ranah konotatif yang mengahasilkan sebuah makna. Maknanya adalah ketika akan melaksanakan sebuah acara prosesi pernikahan, terlebih dahulu melakukan pembentukan panitia pelaksana agar acaranya bisa berjalan lancar dengan adanya panitia yang membantu.

Penjelasan di atas dapat disimpulkan bahwa "pembentukan panitia pernikahan" merupakan kagiatan yang dilakukan oleh warga masyarakat untuk membantu ketika berlangsungnya acara prosesi pernikahan sehingga bisa berjalan lancar dengan adanya panitia yang dibuat. Dalam pembentukan panitia pernikahan terdapat 4 bagian yaitu: penasehat, ketua, sekretaris, dan seksi-seksi. Kemudian dalam seksi-seksi dibagi lagi menjadi 5 bagian yaitu: parenta (orang yang mengetahui segala hal apa saja yang kurang), seksi penerima tamu, seksi perlengkapan/sound system, seksi dapur/konsumsi, dan seksi acara.

\section{Kancihi ncao fiki ro kananu} kasabua ade ro loko (menyelaraskan pikiran dan renungan, menyatukan hati dan rasa).

\section{Keterangan}

Penanda (1 signifier) "kancihi ncao fiki ro kananu kasabua ade ro loko" tanda ini menempati petanda (1) pada ranah denotatif. Penanda tersebut menjelaskan bahwa tahapan kelima yang dilakukan dalam acara Mbolo Weki prosesi pernikahan adalah "kancihi ncao fiki ro kananu kasabua ade ro loko" yang harus di terapkan oleh seluruh warga masyarakat yang hadir agar pembicaraan yang dibahas bisa disepakati oleh semua pihak sehingga tidak ada yang berbeda pendapat. Penanda (1) ini membuahkan petanda (2) pada ranah denotatif. Petanda (2 signified) ini adalah "adanya musyawarah mufakat" Petanda (2) ini menjelaskan bahwa dalam menyelaraskan pikiran dan renungan, menyatukan hati dan rasa biasanya karena adanya sebuah musyawarah mufakat yang akan dilaksanakan dalam mempersiapkan acara hajatan yaitu prosesi pernikahan. Hal ini harus di terapkan oleh seluruh warga masyarakat yang hadir dalam acara Mbolo Weki prosesi pernikahan tersebut agar terciptanya kesepakatan bersama.

Tanda (3 tanda denotatif) pada ranah denotatif ini sekaligus menjadi penanda (I) pada ranah konotatif. Tanda (3/I penanda konotatif) yang dimaksud adalah "untuk mencapai kesepakatan bersama". Tanda ini menjelaskan bahwa tujuan dari menyelaraskan pikiran dan renungan, menyatukan hati dan rasa adalah untuk mencapai kesepakatan bersama sehingga tidak ada yang berbeda pendapat antara satu sama lain. Pada tahap kelima "kancihi ncao fiki ro kananu kasabua ade ro loko", memberikan penjelasan bahwa ketika semua warga masyarakat telah selesai dalam 
bermusyawarah, pastinya akan menyelaraskan pikiran dan renungan, menyatukan hati dan rasa agar acaranya bisa berjalan lancar. Tanda ini terbentuk karena adanya penanda dan petanda para ranah denotatif yang tidak bisa terpisahkan, yang saling melengkapi, sehingga menghasilkan tanda pada ranah denotatif yang sekaligus menjadi penanda pada ranah konotatif. Tanda (3/I) memunculkan penanda (II) pada ranah konotatif yaitu "harus saling mengahargai". Jadi, dalam menyelaraskan pikiran dan renungan, menyatukan hati dan rasa pastinya harus saling menghargai antara satu sama lain agar tidak ada yang berbeda pendapat. Kemudian dari penanda (II petanda konotatif) pada ranah konotatif ini melahirkan tanda (III) pada ranah konotatif yaitu "adanya nilai toleransi".

Tanda (III tanda konotatif) ini merupakan kesimpulan dari pertemuan antara penanda (I) dan petanda (II) pada ranah konotatif yang mengahasilkan sebuah makna. Maknanya adalah ketika acara Mbolo Weki (musyawarah mufakat) prosesi pernikahan telah selesai dilaksanakan pastinya semua warga yang hadir akan menyelaraskan pikiran dan renungan, menyatukan hati dan rasa, tujuannya adalah agar tidak ada yang berbeda pendapat antara satu sama lain sehingga bisa mencapai suatu kesepakatan bersama.

Pada penyajian hasil analisis akan menjelaskan hasil analisis yang didapatkan pada tahap sebelumnya, yakni enam simbol yang sudah ada dan ditemukan berdasarkan bagan semiologi Roland Barthes. Lima simbol tersebut dimasukan ke dalam bagan Roland Barthes sehingga membentuk enam analisis tanda yang salling berkaitan dan mengahsilkan makna. Berikut enam makna yang berhasil

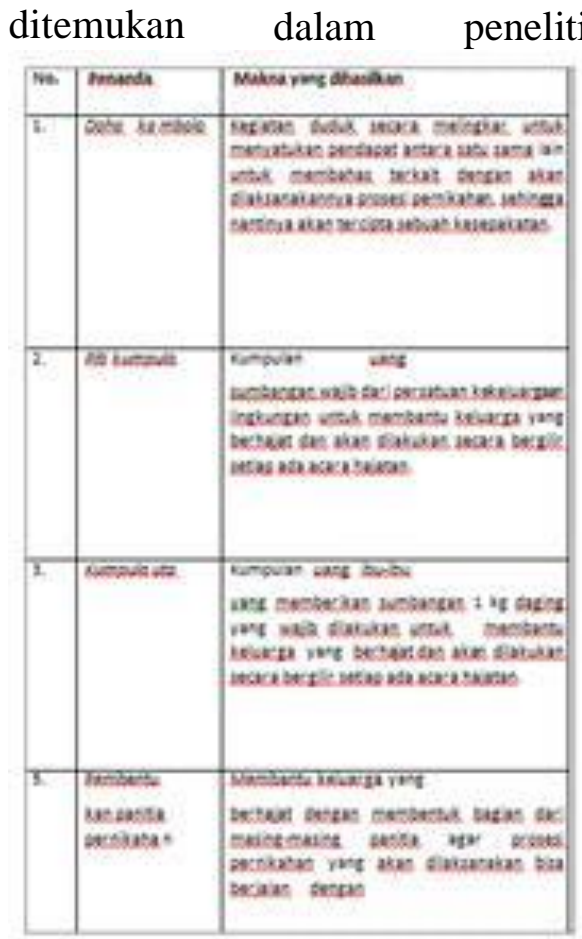

SIMPULAN

Berdasarkan pembahasan bahwa tindakan-tindakan dalam Mbolo Weki prosesi pernikahan tradisi masyarakat Bima dapat disimpulkan yaitu terdapat 6 tanda yaitu, doho ka mbolo, mbei sumbangan, piti kumpula, kumpula uta, pembentukan panitia pernikahan dan yang berbentuk pesan verbal yaitu kancihi ncao fiki ro kananu kasabua ade ro loko. Dari tindakan yang digambarkan tersebut bahwa acara Mbolo Weki prosesi pernikahan memiliki makna bahwa Mbolo Weki merupakan suatu acara yang dilakukan secara terhormat dalam tradisi prosesi pernikahan yang bertujuan untuk mempererat hubungan dalam kesatuan sosial masyarakat, seperti adanya bantuan dari kelompok orang, yang dimaksudkan dengan adanya pemberian sumbangan secara bergilir dengan tujuan salah satunya untuk meringankan beban biaya pernikahan keluarga yang berhajat, dan tradisi ini sangat bermanfaat sekali untuk berbagai kalangan sosial dalam masyarakat suku Bima

\section{DAFTAR PUSTAKA}

Aminuddin. 2015. Semantik. Bandung: Sinar Baru Algensindo. Arikunto. 2013. Prosedur Penelitian. Jakarta: Rineka Cipta. 
Barthes, Roland. 2007. Petualangan Semiologi. Yogyakarta: Kreasi Wacana. Faruk. 2014. Metode Penelitian Sastra. Yogyakarta: Pustaka Belajar.

Hasanah, Nurul. 2015. "Upacara Basentulak di Desa Telagawaru Kecamatan Labuapi Kabupaten Lombok Barat: Kajian Semiotik". Skripsi S1. Universitas Mataram.

Melati, Tily Putri. 2016. "Makna SimbolSimbol Budaya dalam Prosesi Adat Pernikahan di Kabupaten Dompu Kajian Semiotika (Roland Barthes)". Skripsi SI. Universitas Mataram.

Moleong, Lexy J. 2016. Metodologi Penelitian Kualitatif. Bandung: PT Remaja Rosdakarya

Ramadhan, Syahrir. 2016. "Kajian Pragmatik Tradisi Panati dalam Perkawinan Masyarakat Bima di Desa Rato Kecamatan Bolo". Skripsi SI. Universitas Mataram.

Ratna. 2012. Teori, Metode, dan Teknik Penelitian Sastra. Yogyakarta: Pustaka Belajar.

Sakinah. 2017. " Kajian Hermeneutika Gadamer pada Zikir Kalei Bunti di Desa Bolo Kecamatan Madapangga Kabupaten Bima". Skripsi SI. Universitas Mataram.

Semi, Atar. 2012. Metode Penelitian Sastra. Bandung: Angkasa Bandung

Sobur, Alex. 2016. Semiotika Komunikasi. Bandung: PT Remaja Rosdakarya. Yuliani. 2015. "Analisis SimbolSimbol dalam Tradisi Bertimpas di Dusun

Selanglet Lombok Tengah Kajian Semiotika Roland Barthes". Skripsi SI. Universitas Mataram. 